\title{
How Federal Government's Debt Affect the Level of Economic Growth?
}

\author{
Nur Hayati Abd Rahman
}

\begin{abstract}
This paper examines the impact of federal government's debt on the level of economic growth particularly in Malaysia. By using quarterly data from the first quarter of 2000 until the fourth quarter of 2011, it was found that high domestic debt does have negative impact on the level of economic growth in the long-run. However, the level of external debt has no significant influence in changing the economic growth within the same time frame. From the short-run perspective, both domestic and external debts have no significant impact on the level of economic growth. Nevertheless, if there is any shock in the current economic condition, the real GDP is able to restore its equilibrium level in the short-run.
\end{abstract}

Index Terms-Budget Deficit, Domestic Debt, External Debt, Federal Government's Debt.

\section{INTRODUCTION}

It was forecasted that the Malaysia's economy should be growing by six to seven percent per annum in order to achieve a status of a developed country [1]. However, due to uncertainties in global economic condition, it is quite impossible for Malaysia to achieve that figure if its Gross Domestic Product (GDP) relies heavily on the foreign sector. Hence, it is essential for Malaysia to depend on the domestic sectors. For the purpose of sustaining the Malaysia's economic development, the domestic macroeconomic conditions need to be observed carefully especially in terms of inflation, budget deficit, public debt, and interest rate as well as government expenditures.

It was reported that the highest outstanding federal government debt recorded by Malaysia since 2000 was RM 470,759 million. This amount was recorded in the first quarter of 2012. Almost $96 \%$ of the outstanding debt was due to domestic borrowing, while the remaining $4 \%$ was derived from external borrowing [2]. Those debts were mostly financed through the sales of the Malaysian Government Securities (MGS). It is a kind of method used by the government to borrow money from the citizens as well as investors. Due to an increasing demand of MGS in the domestic market, the Malaysian government has no worries on the source of domestic financing.

Even though the percentage of public debt derived from the external borrowing can be considered as lower relative to other developing countries, it is still an alarming condition for Malaysia to observe the debt's level since it may give adverse impacts to the economy. This is consistent with the

Manuscript received June 5, 2012; revised July 15, 2012

The author is with the Universiti Teknologi MARA (Terengganu), Dungun, 23000 Terengganu (e-mail: nurhayati@tganu.uitm.edu.my). fears raised by two prominent researchers in the area of public debt, Carmen Reinhart and Kenneth Rogoff. Based on their findings on the scenarios happened across dozens of countries, it was predicted that the level of public debt will definitely hinder the economic growth if the debt-to-GDP ratio is equal or exceed $90 \%$ threshold [3]. Although the Malaysia's debt-to-GDP ratio does not exceed the threshold, it may give hinder the objective of Malaysia's economic transformation. Thus, this research is conducted to analyze the impacts of public debt on the level of economic growth from Malaysia's perspective.

\section{LITERATURE REVIEW}

By definition, the public debt can be defined as a condition in which the stocks of government securities are insufficient to finance previous budget deficits. Meanwhile, budget deficit happens when the level of government expenditures exceed its revenues.

\section{A. Government Expenditures and Economic Growth}

From the macroeconomic theory, the government expenditures should have positive relationship with the level of economic growth. This theory is then supported by Freeman and Webber (2009), in which they found that the productive type of expenditure such as education, health and nutrition can leads to the economic returns [4]. However, the returns can only be seen in few years time. Those expenditures give direct impact to the improvement of the well-being and basic welfare of the citizens. It then contributes significantly to an increase in labor productivity. As a result, the higher level of economic growth can be achieved.

Nevertheless, if most of the portions of the government expenditures are channeled to unproductive type of expenditures, it may result to a decline in the economic growth [1]. The unproductive type of expenditure includes subsidies, pensions, and etc. In the case of countries within European Union (EU), it was projected that the cost of pension and other retirement funds that need to be paid by the government to the ageing population may cause huge debt to the government. It may reach around $130 \%$ of the total GDP in 2050 [5]. If this much is being spent by the government during that time, the EU members will face with huge budget deficit. If it is not being tackled seriously, the governments of the EU members may encounter with a bigger problem, huge public debt. They may survive from this problem if the life expectancy rate increases from now onwards, provided that the new generation is provided with proper education, medical services and other public goods. 


\section{B. Budget Deficit and Economic Growth}

High budget deficit will definitely reduce the level of economic growth due to the crowd-out effect in loanable fund market [3]. In order to finance additional expenditures, the government will borrow money from the citizens and foreign investors. Since the demand of the loanable funds is derived from the private sector as well, additional demand from the government will boost the interest rate. Consequently, high interest rate will distort the level of investment. Ultimately, lower level of investment constitutes to lower economic growth for a country.

\section{Federal Government's Debt and Economic Growth}

Based on the public debt's perspective, high public debt may result to a financial crisis. If a country is experiencing a trend of an increasing public debt, the investors may be worried about the capabilities of that country to pay its debts to the creditors [3]. Apart from that, the creditors will ask for higher interest rate as a safety and profitable measures for them to keep financing the deficits. A spike in interest rate can distort the level of economic growth and would create financial crisis. This case will happen if the ratio of public debt to GDP is higher than $90 \%$ threshold [3]. The same finding can be concluded based on a research done in numbers of advanced and emerging economies [6].

In addition, a country with more than $60 \%$ external debt out of GDP experiences lower GDP growth rate per annum by $2 \%$ [6]. This is due to the fact that the debt is denominated in a foreign currency which is fluctuating over time based on the economic condition of the creditors' countries.

In opposite, it was also found that high public debt does not hurt the economic growth especially for advanced economies [7]. This is because most of the debts in advanced countries were financed through internal sources.

From the above literatures, mixture of results and analysis can be found. For sure, the problem of federal government's debt raised due to huge government expenditures. From macroeconomic perspective, high expenditures spent by the public sector will definitely stimulate the economic growth. However, if the expenditures exceed the level of revenues generated by the government, it raises new problem called budget deficit. The government can borrow money to finance the deficit from domestic or external sources. The economic condition may or may not be disrupted depending on the current economic condition, the level of federal government's debt and other factors. Hence, this paper is written to analyze the impact of federal government's debt on the economic growth from Malaysia's perspective.

\section{MeTHODOLOGY}

In measuring the relationship between federal government's debt and economic growth, three variables were used namely real Gross Domestic Product at time $t$ $\left(\mathrm{RGDP}_{\mathrm{t}}\right)$, federal government's domestic debt at time $t$ $\left(\mathrm{DDEBT}_{\mathrm{t}}\right)$ and federal government's external debt at time $\mathrm{t}$ $\left(\mathrm{EDEBT}_{\mathrm{t}}\right) . \varepsilon_{\mathrm{t}}$ represents other variables that were not listed but may give impacts to the economic growth .

$$
\mathrm{RGDP}_{\mathrm{t}}=\mathrm{f}\left(\mathrm{DDEBT}_{\mathrm{t}}, \mathrm{EDEBT}_{\mathrm{t}}, \varepsilon_{\mathrm{t}}\right)
$$

All of these variables were transformed into natural logarithm form. Apart from that, the data of these variables consist of quarterly data from the first quarter of 2000 until the fourth quarter of 2011. In investigating the relationship between variables, various methods can be used to investigate the relationship between variables such as Ordinary Least Square (OLS), Johansen Maximum Likelihood cointegration test, panel cointegration technique, Engle-Granger cointegration test, and Autoregressive Distributed Lag (ARDL). In this paper, the Johansen cointegration test is applied since it is able to determine the short-run and long-run relationships between variables. Moreover, it is also capable in determining more than one cointegrating vector [8].

Prior to the cointegration test, there is a need to check the stationarity status of each variable by using unit root test. This is due to the fact that the Johansen cointegration test can only be conducted if all variables are integrated at the same order [9]. In this case, the author had chosen to perform Augmented Dickey-Fuller (ADF) unit root test to every single variable. The main idea is to ensure all variables are stationary at the same order. It is essential to have stationary variables because the regression results based on these variables will not be spurious. In other words, the results can be deemed as reliable.

Once it is confirmed that the variables are integrated at the same order, the Johansen cointegration test can be conducted by forming a standard vector autoregressive (VAR) model. In order to understand the VAR model, let's assume that there are $m$ numbers of variables that are not stationary at level $\left(\mathrm{X}_{1 \mathrm{t}}, \mathrm{X}_{2 \mathrm{t}}, \mathrm{X}_{3 \mathrm{t}}, \ldots, \mathrm{X}_{\mathrm{mt}}\right)$. Assume that these variables will be stationary once it is transformed into first difference (same level of integration), all these $\mathrm{x}$-variables can be combined into a single variable, called $\mathrm{X}_{\mathrm{t}}$. This process is illustrated in equation 2. The main idea of this conversion is to let all $\mathrm{X}$-variables to be an endogenous variable, $\mathrm{X}_{\mathrm{t}}$. As shown in equation 3 , the VAR model can be constructed by letting $X_{t}$ as a function of lagged values of all endogenous variables.

$$
\begin{gathered}
X_{t}=\left(X_{1 t}, X_{2 t}, X_{3 t}, \ldots, X_{m t}\right) \\
X_{t}=A_{1} X_{t-1}+A_{2} X_{t-2}+\ldots+A_{p} X_{t-p}+\varepsilon_{t}
\end{gathered}
$$

Since this VAR model consists of all $\mathrm{x}$-variables that are non-stationary at level, it is essential to convert those variables into first difference. Again, let's assume that all $\mathrm{x}$-variables will become stationary at the first difference. Hence, the new VAR model can be re-write as follows:

$$
\Delta \mathrm{X}_{\mathrm{t}}=\Pi \mathrm{X}_{\mathrm{t}-\mathrm{p}}+\Sigma \Pi_{\mathrm{i}} \mathrm{X}_{\mathrm{t}-1}+\varepsilon_{\mathrm{t}}
$$

In Johansen cointegration test, the author is interested to determine the number of cointegrating vectors, which is illustrated by $\Pi$. If the value of $\Pi$ is zero, it means there is no cointegration between variables. In opposite, if the value is greater or equal to 1 , it is a proof that the cointegration between variables exist. This scenario shows that there exists long-run relationship between variables. Trace and maximum-eigenvalue tests statistic can be applied to determine the number of rank $\Pi$.

Based on Granger Representation Theorem, if there is long-run relationship between variables, the vector error 
correction model (VECM) can be formed. Unlike VAR, this model is able to determine the short-run relationship between variables. EViews software is used to meet the research objective, which is to determine the impact of the federal government's debt to the level of economic growth.

\section{REsults AND Discussion}

The results of the ADF unit root test show that all variables are non-stationary at level. The means and variances of all variables were constant once they were transformed into first difference. In other words, all variables are integrated at the first order; I(1). It can be shown in table 1 as illustrated below. The values in parantheses [ ] represent the probability of the ADF test statistic, while a symbol of * shows that the variable is significant or stationary at five percent confidence level.

TABLE I: THE RESULTS OF THE ADF UNIT ROOT TEST

\begin{tabular}{|c|c|c|}
\hline Variable & Level & First Difference \\
\hline RGDP & -0.454209 & -5.013141 \\
& {$[0.8900]$} & {$[0.0002 *]$} \\
\hline DDEBT & -0.237133 & -6.606915 \\
& {$[0.9261]$} & {$\left[0.0000^{*}\right]$} \\
\hline EDEBT & -0.539353 & -5.608192 \\
& {$[0.8739]$} & {$\left[0.0000^{*}\right]$} \\
\hline
\end{tabular}

Prior to the execution of the Johansen cointegration test, the number of lag to be used in VAR model need to be carefully examined. According to LR test statistic, it indicates that three lags were sufficient in removing the autocorrelation of the residuals in the VAR model. By supporting with the normality tests of the residuals in VAR, it is proven that the VAR residuals are multivariate normal. This result is based on the null hypothesis that the residuals are multivariate normal. Hence, the author uses three lags in the VAR model. Refer to table 2 that illustrate the normality test of the VAR residuals.

TABLE II: VAR RESIDUAL NORMALITY TEST

\begin{tabular}{|c|c|}
\hline Component & Probability \\
\hline Skewness & 0.5133 \\
\hline Kurtosis & 0.3505 \\
\hline Jarque-Bera & 0.4724 \\
\hline
\end{tabular}

By letting all specified variables as endogenous variables, the trace test indicates that there is one cointegrating equation at five percent confidence level. By referring to table 3, rank 1 is chosen since the value of trace statistic is less than the critical value. Besides, the null hypothesis of no cointegrating equation is rejected due to its probability which is less than 0.05. However, the null hypothesis of at most one cointegrating equation is accepted since the probability of 0.0665 is greater than the critical value of 0.05 .

TABLE III: UNRESTRICTED COINTEGRATION RANK TEST

\begin{tabular}{|c|c|c|c|}
\hline $\begin{array}{c}\text { Null } \\
\text { Hypothesis: } \\
\text { No. of CE(s) }\end{array}$ & $\begin{array}{c}\text { Trace } \\
\text { Statistic }\end{array}$ & $\begin{array}{c}\text { Critical } \\
\text { Value }\end{array}$ & Probability \\
\hline None & 31.00296 & 29.79707 & 0.0362 \\
\hline At most 1 & 14.66084 & 15.49471 & 0.0665 \\
\hline At most 2 & 0.119477 & 3.841466 & 0.7296 \\
\hline
\end{tabular}

Since it is proven that the variables are cointegrated by at most one cointegrating equation, the long-run coefficients can be estimated. The normalized cointegrating coefficients for the independent variables are illustrated in table 4 as shown below.

TABLE IV: NORMALIZED COINTEGRATING COEFFICIENTS

\begin{tabular}{|c|c|c|}
\hline Variables & Coefficients & T-Statistics \\
\hline DDEBT & -0.558538 & $-11.7200^{*}$ \\
\hline EDEBT & -0.011033 & -0.26462 \\
\hline
\end{tabular}

* indicates that the variable is significant at $5 \%$ confidence level.

By referring to the results tabulated in table 4, federal government's domestic debt is the only significant variable in explaining the economic growth in the long-run. This is because the absolute value of t-statistic is greater than two. In other words, if the federal government's domestic debt increases by one percent, the real GDP will reduce by $0.55 \%$. This result is consistent with other researchers that found the federal government's debt distorts the economic growth of a country. However, there is no such evidence to confirm the impact of the external debt on the level of economic growth in the long-run.

From the short-run perspective, the impact of both types of federal government's debt on the level of real GDP is illustrated in table 5 .

TABLE V: ERROR CORRECTION MODEL (ECM)

\begin{tabular}{|c|c|c|}
\hline Variables & Coefficients & T-Statistics \\
\hline ECM & -0.419943 & $-3.09091^{*}$ \\
\hline RGDP(-1) & 0.435854 & $2.61760^{*}$ \\
\hline RGDP(-2) & 0.337422 & $2.32231^{*}$ \\
\hline RGDP(-3) & 0.150223 & 0.96444 \\
\hline DDEBT(-1) & -0.189970 & -0.70706 \\
\hline DDEBT(-2) & -0.222946 & -0.86589 \\
\hline DDEBT(-3) & -0.179555 & -0.65784 \\
\hline EDEBT(-1) & -0.114599 & -1.69367 \\
\hline EDEBT(-2) & -0.105616 & -1.68694 \\
\hline EDEBT(-3) & -0.030293 & -0.46966 \\
\hline
\end{tabular}

* indicates that the variables are significant at $5 \%$ confidence level.

As illustrated in table 5, past two years of real GDP are the only variables that have significant influence in changing the level of current real GDP. This is because the absolute values of the t-statistics are greater than two. The domestic debt and external debt have no significant impact on the economic growth in the short-run. Apart from that, the sign for ECM is negative and significant. It means that there is a tendency for the real GDP to restore its equilibrium in the short-run.

\section{CONCLUSION}

In conclusion, the Malaysian economy may not be able to achieve high and sustainable economic growth in the long-run if the federal government keeps borrowing money from the domestic market in order to finance the budget deficit. However, there is no such evidence to conclude that the external debt can distort the economic growth in the long-run.

From the short-run perspective, the current real GDP can 
only be changed if there is any change in the past two years of real GDP. Besides, there is a tendency for the real GDP to restore back to its equilibrium level if there is any shock in the economy.

\section{REFERENCES}

[1] A. R. Nur Hayati, "The relationship between budget deficit and economic growth from Malaysia's perspective," in International Proceedings of Economics Development and Research, Singapore, 2012, pp. 54-58

[2] Central Bank of Malaysia. Federal government debt: Classification by currency and remaining maturity. Monthly Statistical Bulletin, Central Bank of Malaysia. [Online]. Available: http://www.bnm.gov.my/index.php?ch=en_publication_catalogue\&pg $=e n \_$publication_msb\&mth=5\&yr=2012\&lang=en, March 2012.

[3] J. Bivens and J. Irons, "Government debt and economic growth," Economic Policy Institute. [Online]. Available: http://www.epi.org/publication/bp271, July 2010.

[4] S. M. Freeman, and D. J. Webber, "Basic needs, government debt and economic growth," The World Economy., vol. 32, no. 6, pp. 965-994, June 2009 .
[5] G. Carone, D. Costello, N. Z. Guardia, P. Eckefeldt, and G. Mourre, "Economic growth and fiscal sustainability in the EU: The impact of an ageing population," 2012.

[6] C. M. Reinhart and K. S. Rogoff, "Growth in a time of debt," The National Bureau of Economic Research, no. 15639, pp. 2-25, Jan 2010

[7] U. Panizza and A. F. Presbitero, "Public debt and economic growth: Is there a causal effect," POLIS Working Papers, no. 198, pp. 1-47, 2012.

[8] E. C. Tan, "Money demand, bank credit and real exchange rates in a small open developing economy: An econometric analysis for Malaysia," Ph.D. dissertation, Department of Economics, University of Warwick, United Kingdom, 1995.

[9] A. R. Nur Hayati, "The influence of credit card usage on money demand in Malaysia," Master dissertation, Department of Economics, University of Malaya, Malaysia, 2010.

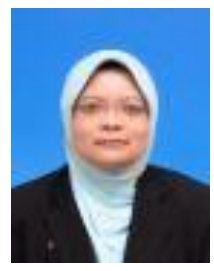

Nur Hayati Abd. Rahman was born in Kuala Lumpur, Malaysia on $28^{\text {th }}$ November 1984. She received her Bachelor Degree in Economics from the International Islamic University of Malaysia (IIUM) in 2007. Then, she pursued her Master education in University of Malaya and received Master in Economics in 2011.

Currently, she is working as a LECTURER in Universiti Teknologi MARA (Terengganu), Malaysia. Her area of interest is particularly on the fiscal policy and econometric analysis. 